\title{
Arabic Names Occurring in the Map and Report on Southern Palestine
}

\section{G. Schumacher}

To cite this article: G. Schumacher (1886) Arabic Names Occurring in the Map and Report on Southern Palestine, Palestine Exploration Quarterly, 18:4, 194-197, DOI: 10.1179/ peq.1886.18.4.194

To link to this article: http://dx.doi.org/10.1179/peq.1886.18.4.194

曲 Published online: 20 Nov 2013.

Submit your article to this journal $₫$

Џ Article views: 5

Q View related articles $\square$ 
now and then a natural basin of rain-water, to the welcome of both rider and horse; and as to safety, I would state, as already mentioned by Mr. Guy le Strange, on the occasion of his "ride through the Belka" ("Across the Jordan," p. 323), that if with little baggage the explorer contents himself with Bedouin tents, comfort and costumes, and accompanied by a native guide, well known to the tribes, may travel even in these ill-renowned regions and still farther east without fear; and if he has any knowledge of Arabic, then I would recommend dress as an A rabian, and to adopt a Mohammedan name, as done by myself.

HaIfA, July, 1886.

G. Schumacher.

\section{ARABIC NAMES OCCURRING IN THE MAP AND REPORT ON SOUTHERN PALESTINE.}

By $G$. Schumacher.

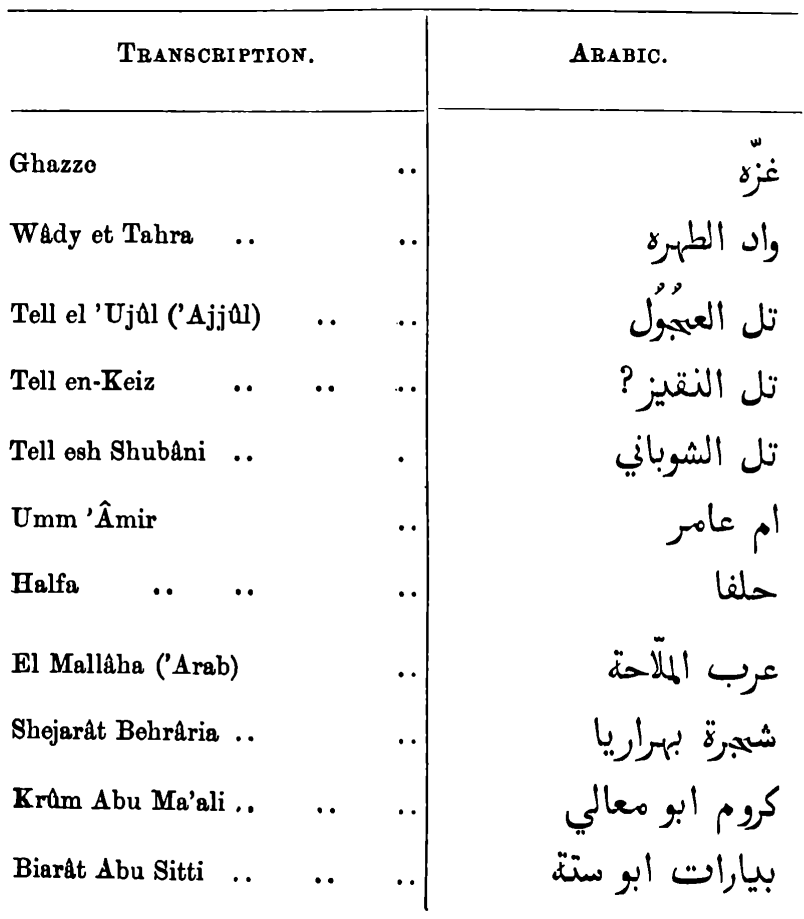




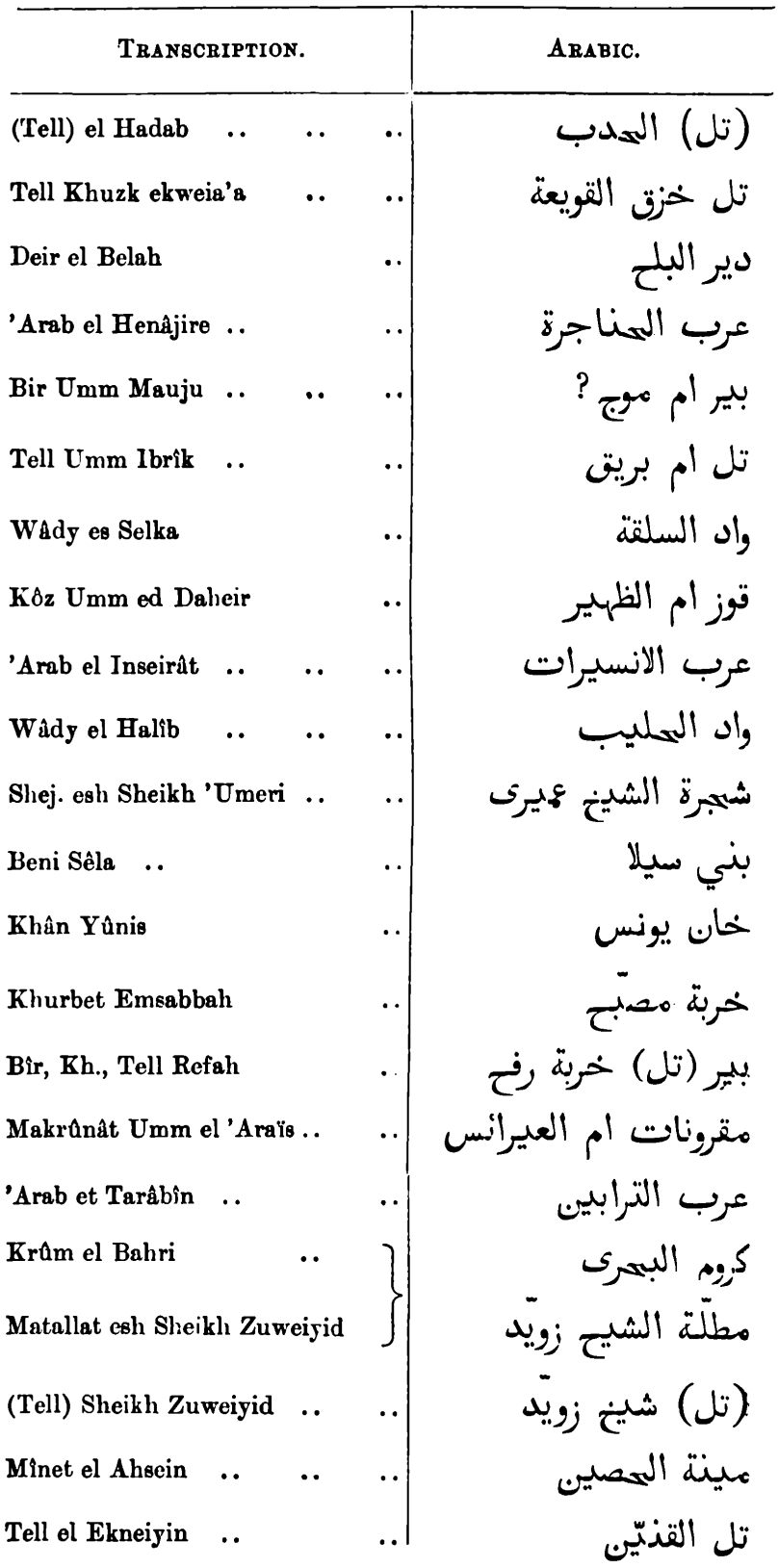




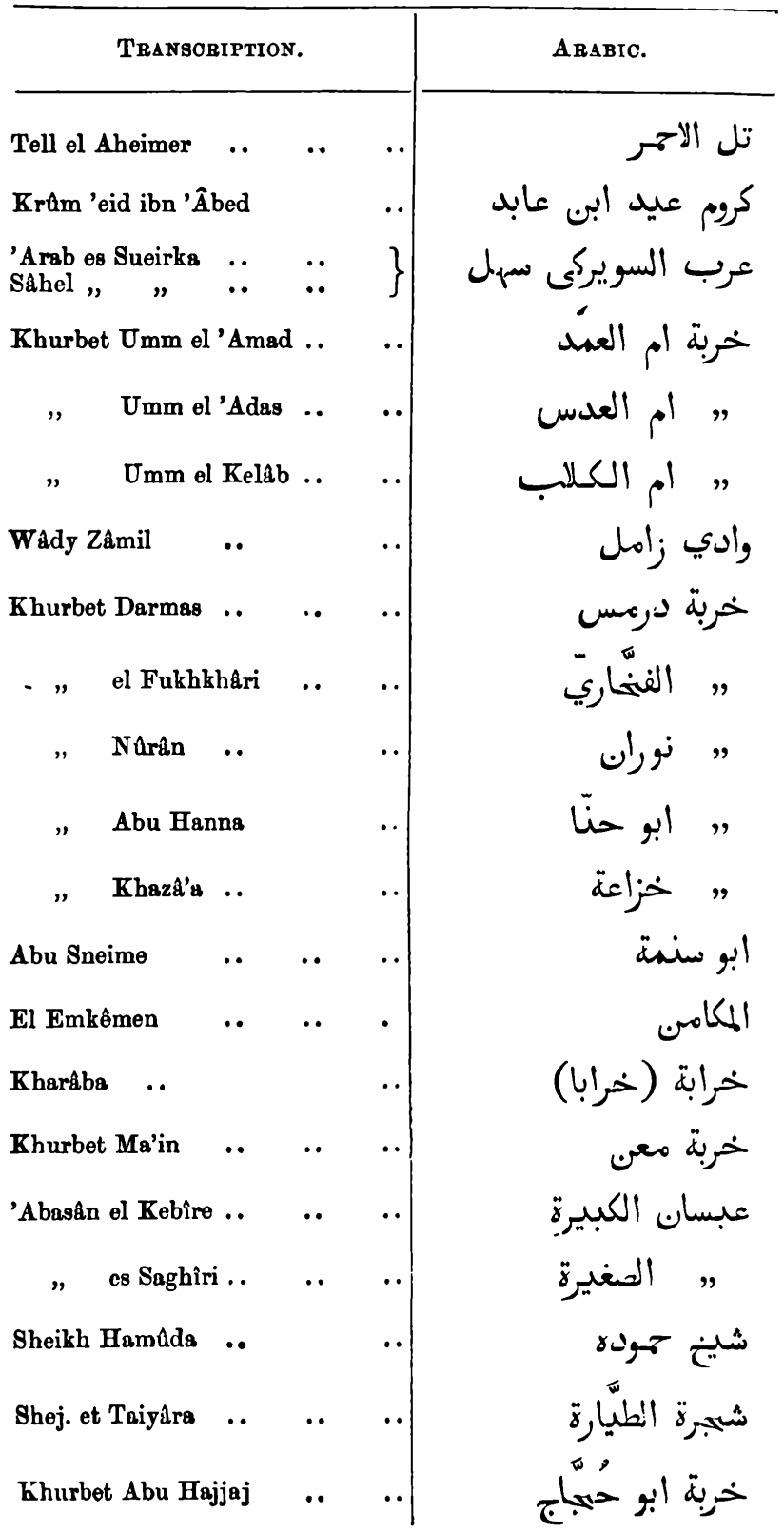




\begin{tabular}{|c|c|c|}
\hline \multicolumn{2}{|c|}{ Transcription. } & Arabic. \\
\hline Khurbet Inseirat ... &.. & خربة انسيرات \\
\hline Shejarat el Maghaza & .. & شمبرة الثغزا| ? \\
\hline Ed Dmeita .. $\quad$.. & . & الد مائة ? \\
\hline Khurbet $\Delta$ bu el 'Ajîn & $\begin{array}{ll}. & . .\end{array}$ & خربة ابو العميلن \\
\hline
\end{tabular}

\section{SECOND AQUEDUCT TO THE POOL OF SILOAM.}

Durina the stay here of Professor Hayter Lewis, he suggested that I should, at a proper time and opportunity, make some excavations at Siloah on purpose to find traces of the old or first water conduit from the Virgin's Fountain, as I suggested in a former paper, published in Quarterly Statement, A pril, 1886, page 88. This work I completed last month, and it is now my privilege to report upon it. I have prepared the accompanying drawings, based on the printed plan he gave me, and on which he narked in red the exact sites where the excavations should be made.

The first shaft $A$ was made in the very line, but about 40 feet south of the selected point, as the ground was there about 6 feet lower and waste, whereas at the selected spot cauliflower were planted, and the proprietor was not willing to allow excavations. Of course there was no great difference in regard of the expected result.

As the surface of the ground, where the shaft was made, is marked on the Ordnance Map, 2,099, and the bottom of Virgin's Well 2,087 feet, I hoped at the depth of about 12 to 15 feet to find the conduit. We found the following :-

At 9 feet deep, met on the east side a wall which enabled us to go down deep, without wooden frames; but the hewn stones (only two layers) soon ended, and beneath them were uuhewn rubble stones. I wished to know the depth at which the rock lies, and to ascertain its slope, so as to find the real valley.

At 14 feet deep the earth ended and a layer of small stones came and after it a thick layer of sand, with many small pieces of pottery, as if it had once been the watercourse of the valley. At about 20 feet, or 2,079 above the sea, when this layer ended, there was no rock, but stonts and 